Science, Technology and Development 34 (1): 27-34, 2015

ISSN 0254-6418 / DOI: 10.3923/std.2015.27.34

(C) 2015 Pakistan Council for Science and Technology

\title{
Climate Change and its Impacts on Growth of Blue Pine (Pinus wallichiana) in Murree Forest Division, Pakistan
}

\author{
Ghulam Ali Bajwa, Muhammad Kashif Shahzad and Hamad Khalid Satti \\ Pakistan Forest Institute, Peshawar, Pakistan
}

\begin{abstract}
Climate change and its impacts were assessed on growth of Blue pine, Pinus wallichiana in Murree Forest Division. Change in temperature (maximum, minimum, mean) and precipitation was assessed for time period of $1963-2012$ at $50 \times 50 \mathrm{~km}^{2}\left(0.5^{\circ} \times 0.5^{\circ}\right)$. Growth of $P$. wallichiana was measured in terms of ring-width, intra-ring early and late wood formation. The regime of maximum temperature, minimum temperature and mean temperature were estimated and found $26.45 \pm 0.08^{\circ} \mathrm{C}, 13.40 \pm 0.08^{\circ} \mathrm{C}$ and $19.90 \pm 0.07^{\circ} \mathrm{C}$, respectively, while the precipitation regime was $1148.79 \pm 32.87 \mathrm{~mm} / \mathrm{annum}$. An increase of $0.60,1.27$ and $0.98^{\circ} \mathrm{C}$ was observed in maximum temperature, minimum temperature and mean temperature, respectively. Precipitation increased to $28.88 \%$ during time period of 50 years. The mean ring-width, intra-ring early and late wood formation was $1.05 \mathrm{~mm}, 66.2$ and 33.8\%, respectively. The ring-width and intra-ring late wood formation increased by 5.09 and $2.57 \%$, respectively, while the intra-ring early wood formation decreased by $1.28 \%$. The impact of minimum temperature was significant $(0.05)$ on the ring-width. There was a positive but non-significant correlation between temperature (maximum, minimum, mean) and positive and highly significant $(\mathrm{p}<0.01)$ correlation between precipitation and ring-width. The intra-ring early wood formation showed negative correlation with maximum temperature and precipitation, while intra-ring late wood formation showed negative correlation with mean temperature and with intra-ring early wood formation. Ring-width and intra-ring wood formation provided better prediction of impacts of climate change on growth of $P$. wallichiana.
\end{abstract}

Key words: Climate change, impacts, Pinus wallichiana, growth ring, Pakistan

\section{INTRODUCTION}

Climate change is a global concern occurring due to several factors, such as, biotic processes, variation in solar radiation received by the Earth, movement in tectonic plates, volcanic eruptions and anthropogenic activities (Grunewald et al., 2009). Among these factors, human activities have been recognized as significant cause of recent climate change (Knutson et al., 2006). The mean global temperature on the Earth can rise by seven Celsius $\left(7^{\circ} \mathrm{C}\right)$ by the end of 21 st century as compared to the pre-industrial era if present physical changes occurring in the nature and anthropogenic activities are continued. This temperature increase would be much greater and faster as compared to the one of the Earth experienced at the end of last Ice age about 15,000 years (Vorholz, 2009).

This changing climate can adversely affect forest ecosystems, biodiversity, biomass production and ultimately the socio-economic conditions of the man. Temperature and precipitation are two major climatic factors that show significant effects on forest ecology, plant distribution, productivity and health (Allen et al., 1998; Kirschbaum, 2000; Bukhari and Bajwa, 2012). The emerging climate scenarios may cause shift in local and regional flora and fauna (Urban and Shugart, 1989;
Siddiqui et al., 1999; Sala et al., 2000), forest productivity (Boisvenue and Running, 2006) and occurrence of diseases and insect pest attack on plant species (Breshears et al., 2005; Allen et al., 2010; Bukhari and Bajwa, 2012). Apart from these effects, climate change and subsequent biotic changes can lead rapidly to longterm modifications in ecosystems, water and carbon cycling rates and soil surface properties including erosion, albedo, snow melt dynamics and wind turbulence (Urban and Shugart, 1989).

Murree Forest Division (MFD) is outer part of the Western Himalayan Eco-region that is recognized as one of the Global 200 Eco-regions (G200) of the World. MFD has ecological specialty being comprised two ecological zones including: (i) Moist Temperate Forest and Sub-tropical pine Forest (Roberts, 1992). The Forest Division harbor precious conifer species, like Blue pine (Pinus wallichiana) and Chir pine ( $P$. roxburghii). Any climate change in this area thus warrants effects on a large biome. Present study was, therefore, conducted to assess (i) Climate change in MFD and (ii) It impacts on growth of $P$. wallichiana. Diameter growth ring and intra-ring wood formation were used for assessing climate impacts as these are reliable indicators for estimating effects of recent climatic and environmental changes on tree growth (Jacoby and D'Arrigo, 1997; Fonti et al., 2010). 


\section{MATERIALS AND METHODS}

The study was conducted in Murree Forest Division (33'51'49.75' $\mathrm{N}$ to $73^{\circ} 23^{\prime} 20.02^{\prime \prime} \mathrm{E}$ ) for assessing climate change and its impacts on the Blue pine, Pinus wallichiana, during 2014.

A gridded map of Pakistan, compatible with the Climate Research Unit (CRU), having a grid size of $0.5^{\circ} \times 0.5^{\circ}(50 \times 50) \mathrm{km}^{2}$ was prepared for extracting data for climate parameters including: temperature (maximum, minimum and mean) and precipitation over the time period of 1963-2012. Landcover Map of Murree has been shown in Fig. 1.

Four sample plots were selected, at random for taking increment cores. A total of 20 trees, five trees per plot were selected. Two cores (uphill and downhill) per tree were taken using a Pressler's Increment Borer. The cores were preserved in tubes to save them from drying and damage. In Annual Growth Ring Laboratory, Pakistan Forest Institute, the increment cores were processed using different grades of sand paper, coarse to fine. The cores were fixed in the frame and moistened with facial cream. The ring-width, intra-ring early and late wood formation were measured using Digital Positio-meter.

The temperature and precipitation regimes were calculated along with their changing trends. Significance of change in climate, ring-width and intra-ring early and late wood formation was tested applying regression analysis and students t-test. Correlation among climate parameters and growth parameters was established using Pearson correlation matrix. The data were analyzed using statistical software Minitab Version 15.1. A value of $\mathrm{p}<0.05$ was considered statistically significant.

\section{RESULTS}

The results showed $26.5 \pm 0.08^{\circ} \mathrm{C}$ regime of maximum temperature, while $13.4 \pm 0.08^{\circ} \mathrm{C}$ regime of minimum temperature, during time period of 1963-2012, in Murree Forest Division. The mean temperature regime was $19.90 \pm 0.07^{\circ} \mathrm{C}$. The precipitation regime was $1148.8 \pm 32.87 \mathrm{~mm} / \mathrm{annum}$ during the same period (Table 1). The maximum temperature increased significantly $(\mathrm{p}<0.05)$ by $0.60^{\circ} \mathrm{C}$, while the increase in minimum temperature was $1.27^{\circ} \mathrm{C}$, which was highly significant $(\mathrm{p}<0.01)$. The mean temperature broadly followed pattern of minimum temperature and increased by $0.98^{\circ} \mathrm{C}$. The precipitation increased by $28.88 \%$.

Results showed an overall increasing trend in maximum temperature over MFD. The highest maximum temperature was $27.6^{\circ} \mathrm{C}$, during 1999 , followed by $27.5^{\circ} \mathrm{C}$, during 2001 . The lowest maximum temperature

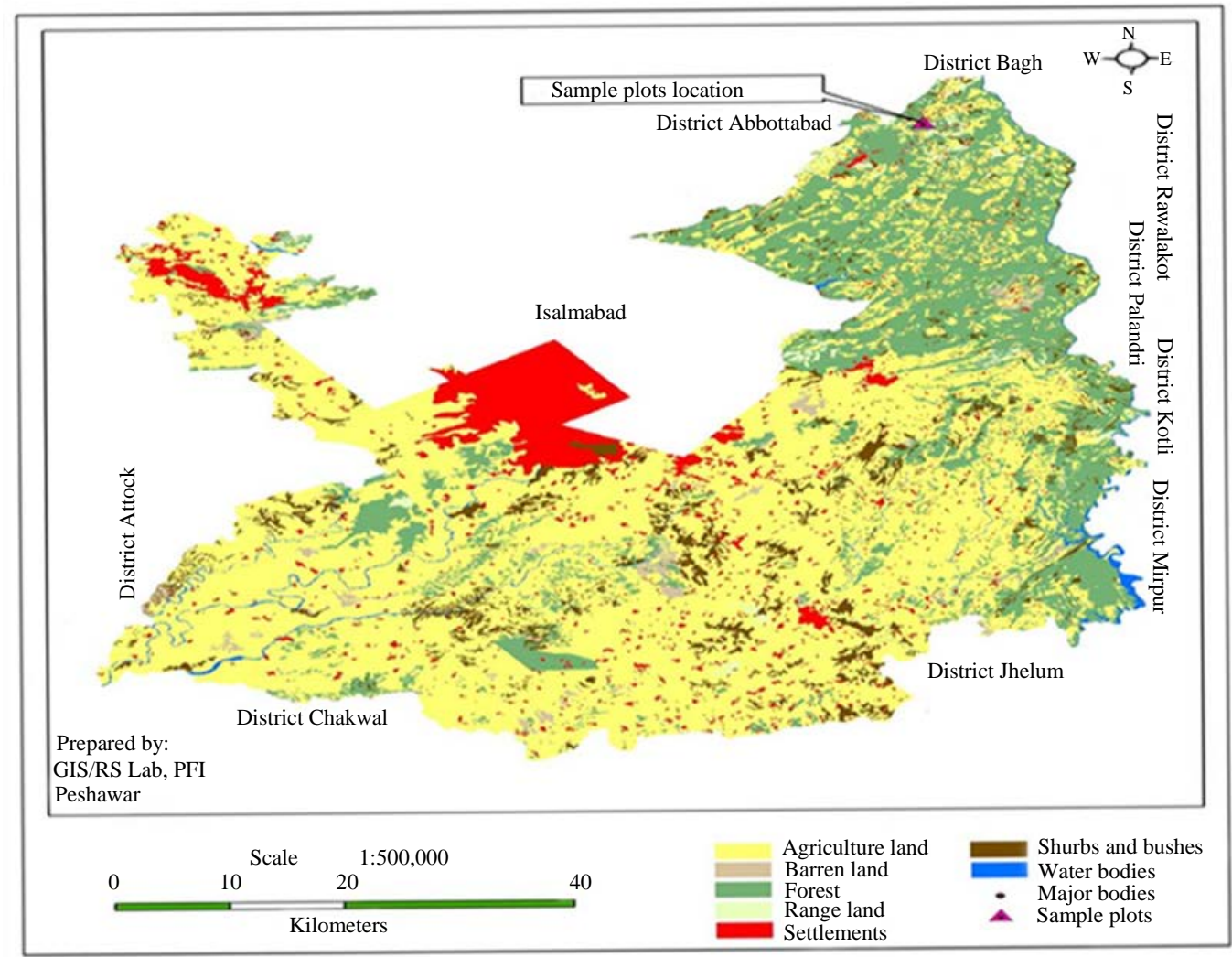

Fig. 1: Landcover map of Murree and sites for collection of wood cores 
Sci. Technol. Dev., 34 (1): 27-34, 2015

Table 1: Climate regimes and changes over MFD (1963-2012)

\begin{tabular}{|c|c|c|c|c|}
\hline Climate parameters & Regime \pm SE & $\Delta$ Change & Mathematical express & $\mathrm{R}^{2}$ \\
\hline Maximum temperature $\left({ }^{\circ} \mathrm{C}\right)$ & $26.45 \pm 0.08$ & $+0.60^{*}$ & $\mathrm{y}=1.944+0.012 \times \mathrm{X}$ & $\overline{0.10}$ \\
\hline Minimum temperature $\left({ }^{\circ} \mathrm{C}\right)$ & $13.40 \pm 0.08$ & $+1.27 * *$ & $y=-38.258+0.026 \times X$ & 0.44 \\
\hline Mean temperature $\left({ }^{\circ} \mathrm{C}\right)$ & $19.90 \pm 0.07$ & $+0.98 * *$ & $y=-20.111+0.02 x * X$ & 0.29 \\
\hline Precipitation $\left(\mathrm{mm}\right.$ anum $\left.{ }^{-1}\right)$ & $1148.79 \pm 32.87$ & $+290.48 * *(28.88 \%)$ & $y=-10631+5.928 \times X$ & 0.13 \\
\hline
\end{tabular}

*Significant at 95\% ( $<<0.05),{ }^{* * \text { Significant at } 99 \%(\mathrm{p}<0.01)}$

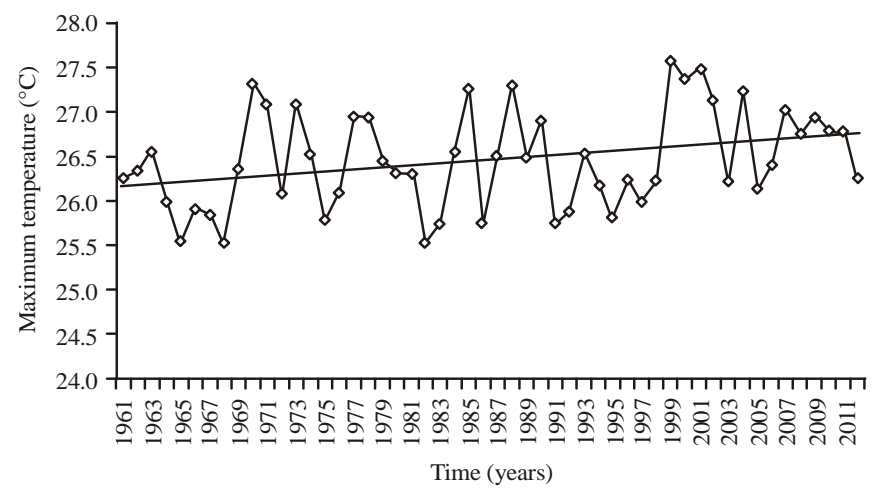

Fig. 2: Changing trends of maximum temperature over MFD (1963-2012)

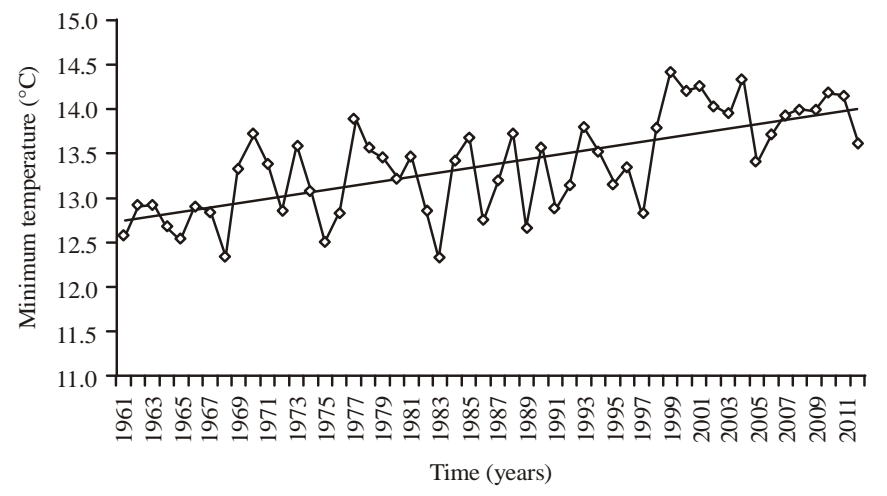

Fig. 3: Changing trends of minimum temperature over MFD (1963-2012)

was $25.5^{\circ} \mathrm{C}$, during 1968 , followed $25.6^{\circ} \mathrm{C}$, during 1982 (Fig. 2). Ten years between 1999 and 2012 have had considerably greater maximum temperature compared to the mean maximum temperature of time period of 1963-2012. The highest variability in the maximum temperature was observed during 1968, while the lowest variability in the maximum temperature was observed during 2004.

Minimum temperature also showed a steady increase over MFD. The highest minimum temperature was $14.5^{\circ} \mathrm{C}$, during 1999 , followed by $14.4^{\circ} \mathrm{C}$, during 2004 . The lowest minimum temperature was $12.3^{\circ} \mathrm{C}$, during 1983, followed by 12.5, during 1975 (Fig. 3). The increase in minimum temperature between 1998 and 2012 was relatively greater compared to time period of 1963-1997. The highest variability in the minimum temperature was during 1963, while the lowest variability in the minimum temperature was during 2004. Furthermore, the slope of increase in minimum temperature was greater compared to the maximum temperature.

The pattern of change in mean temperature was almost similar to the minimum temperature. The highest mean temperature was $21.0^{\circ} \mathrm{C}$, during 1999 , while the lowest mean temperature was $18.9^{\circ} \mathrm{C}$, during 1968 (Fig. 4). The increase in the mean temperature was greater compared to the maximum temperature. The highest variability in the mean temperature was during 1968, while the lowest variability in the minimum temperature was during 2004.

There was a great variability in precipitation ranging between $561.8 \mathrm{~mm} /$ annum and $1635 \mathrm{~mm} / \mathrm{annum}$. However, mean precipitation showed an overall increasing trend over MFD. The highest precipitation received was $1635.0 \mathrm{~mm} / \mathrm{annum}$, during 2006, followed 
Sci. Technol. Dev., 34 (1): 27-34, 2015

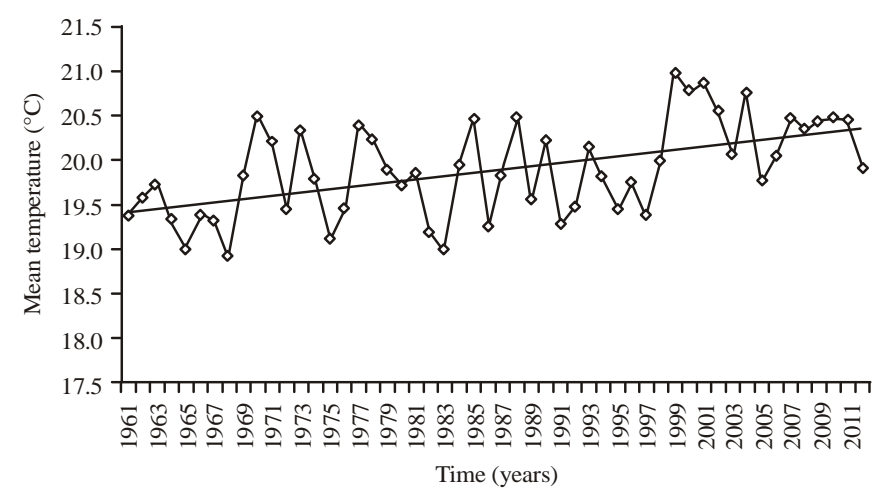

Fig. 4: Changing trends of mean temperature over MFD (1963-2012)

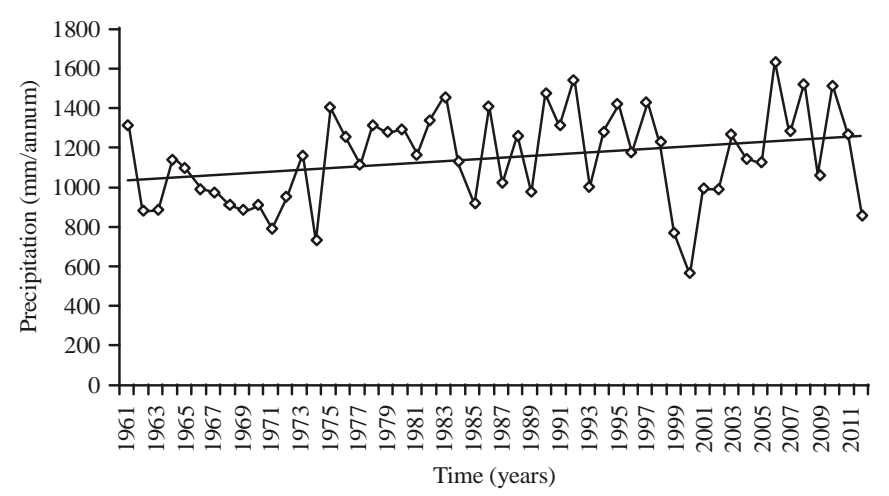

Fig. 5: Changing trends of precipitation over MFD (1963-2012)

Table 2: Statistics of ring-width of $P$. wallichiana in MFD (1963-2012)

\begin{tabular}{lccc}
\hline Statistics & Ring-width $(\mathrm{mm})$ & Early wood (\%) & Late wood (\%) \\
\hline Mean & 1.05 & 66.05 & 33.95 \\
Standard Error $(\mathrm{SE})$ & 0.02 & 0.45 & 0.43 \\
Variance $\left(\sigma^{2}\right)$ & 1.03 & 0.03 & 0.01 \\
Co-efficient of Variance $(\mathrm{CV})$ & 26.82 & 15.77 & 2.30 \\
Change $(\%)$ & $(+) 5.09 *$ & $(-) 1.28^{\text {ns }}$ & $(+) 2.57^{\text {ns }}$ \\
\hline
\end{tabular}

*Significant at $99 \%(\mathrm{p}<0.01)$, ns: Non-significant, +: Increase, -: Decrease

by $1536.4 \mathrm{~mm} / \mathrm{annum}$, during 1992 . The lowest precipitation was $561.8 \mathrm{~mm}$ during 2000, followed by $729.3 \mathrm{~mm} / \mathrm{annum}$, during1974 (Fig. 5). The highest variability in precipitation was found during 2010, while the lowest variability in precipitation was during 2000.

The mean ring-width of $P$. wallichiana was $1.05 \pm 0.02 \mathrm{~mm}$. The mean intra-ring early wood formation was $66.05 \pm 0.45 \%$, while the intra-ring late wood formation was $33.8 \pm 0.43 \%$ (Table 2). The Coefficient of Variation (CV) was calculated for low frequency component variability induced either by climate or by other long term influences. The results of CV calculated indicated enough variability in growth measurement to enable its time function, regression and correlation analyses with changing climate parameters.

A significant $(\mathrm{p}<0.01)$ increase of $5.09 \%$ in ring-width was observed. The largest ring-width was
$1.25 \pm 0.03 \mathrm{~mm}$, during 2008, while the smallest ring-width was $0.99 \pm 0.04 \mathrm{~mm}$, during 1968 (Fig. 6).

The intra-ring early wood formation decreased to 1.28 percent. However, this decrease in intra-ring early wood formation was not significant $(\mathrm{p}>0.05)$. The largest intra-ring early wood formation was $68.7 \pm 1.24 \%$, during 1968 , while the smallest intra-ring early wood formation was $63.4 \pm 1.18 \%$, during 1982 (Fig. 7).

Contrary to intra-ring early wood formation, late wood formation increased to $2.57 \%$. This increase in intra-ring late wood formation was not significant ( $>0.05)$. The largest intra-ring late wood formation was $36.6 \pm 0.87 \%$, during 2006, while the smallest intra-ring late wood formation was 31.3 $\pm 1.25 \%$, during 1967 (Fig. 8).

The results showed a positive linear correlation between temperature (maximum, minimum, mean) 
Sci. Technol. Dev., 34 (1): 27-34, 2015

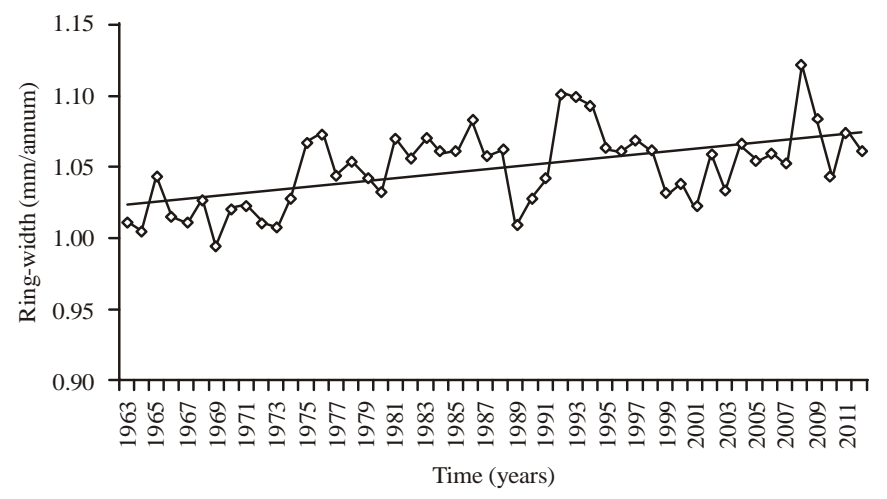

Fig. 6: Time function of blue pine ring-width (mm/annum) in MFD (1963-2012)

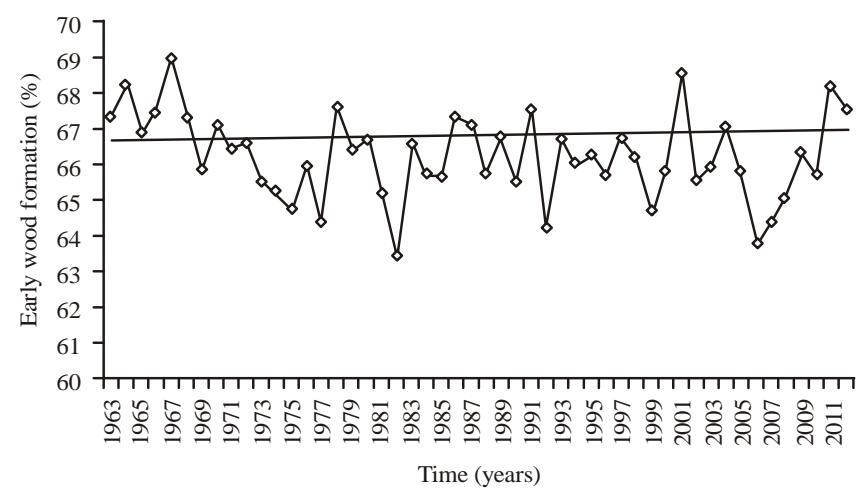

Fig. 7: Time function of blue pine intra-ring early wood formation (\%) in MFD (1963-2012)

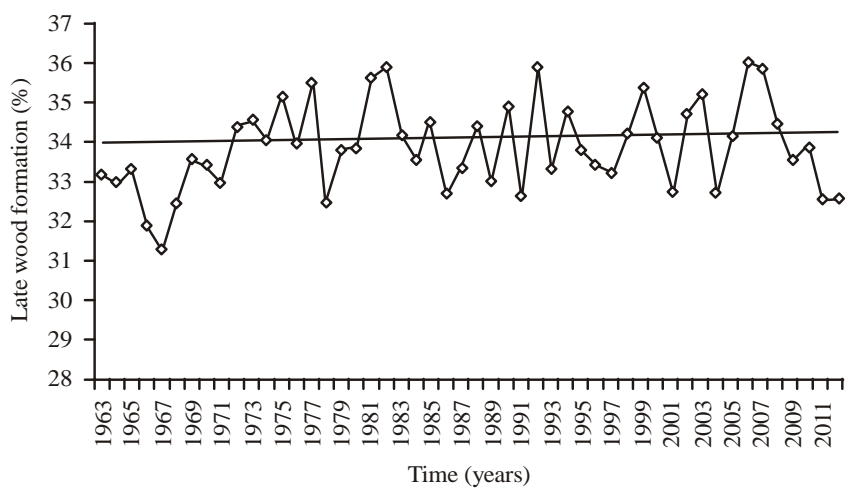

Fig. 8: Time function of blue pine intra-ring late wood formation (\%) in MFD (1963-2012)

Table 3: Correlation matrix among blue pine growth and climate parameters over MFD (1963-2012)

\begin{tabular}{lcccccc}
\hline Growth parameters & Max. Temp. & Min. Temp. & MeanTemp. & Precipitation & Ring width & Early wood \\
\hline Ring-width & $0.03(0.87)$ & $0.21(0.15)$ & $0.08(0.56)$ & $0.51(0.00)$ & - & - \\
Early wood & $-0.02(0.88)$ & $0.05(0.74)$ & $0.08(0.60)$ & $-0.16(0.28)$ & $-0.28(0.04)$ & - \\
Late wood & $0.18(0.22)$ & $0.01(0.95)$ & $-0.01(0.96)$ & $0.08(0.58)$ & $0.27(0.05)$ & $-0.91(0.00)$ \\
\hline
\end{tabular}

and ring-width and between precipitation and ring-width (Table 3). The correlation between temperature (maximum, minimum, mean) and ring-width was not significant $(\mathrm{p}>0.05)$. Conversely, correlation between precipitation and ring-width was highly significant $(\mathrm{p}<0.01)$. A significant $(\mathrm{p}<0.05)$ and negative correlation was found between ring-width and intra-ring early wood formation. A significant $(\mathrm{p}<0.05)$ and positive correlation was found between ring-width and intra-ring late wood formation. The relationship between intra-ring early wood 
formation and intra-ring late wood formation was highly significant $\left(\mathrm{p}^{<0.01)}\right.$ but negative.

\section{DISCUSSION}

The results show a temporal increase of 0.60 and $1.27^{\circ} \mathrm{C}$ in the maximum and minimum temperature, respectively, during 1963-2012 over Murree Forest Division. The present increasing trend in temperature is in corroboration with global temperature increasing trends (Esper et al., 2002; IPCC., 2007). In context of Pakistan, these findings are broadly in conformity with Bukhari and Bajwa (2008), where they reported an increase of 0.92 and $0.77^{\circ} \mathrm{C}$ (mean $0.85^{\circ} \mathrm{C}$ ) in the maximum and minimum temperature, respectively, during 1985-09 in Peshawar. Bukhari and Bajwa (2011) also found an increase of $0.56-0.78^{\circ} \mathrm{C}$ in mean temperature over different forest types of Pakistan. The slight variation in present temperature increase and previously reported temperature increase may be explained in terms of different degrees of albedo, physical nature of soil surface and anthropogenic activities, which influence the spatio-temporal changes in climate processes at local and regional levels (IPCC., 2007; Foley et al., 2005; Falcucci et al., 2007).

The present greater increase in temperature at local level compared to global average temperature increase of $0.74^{\circ} \mathrm{C}$ during $1906-2005$ (IPCC., 2007), apart from other factors, might be due to rapid urbanization, overwhelming tourism, especially during summer and winter in the area, and changes in land use patterns. These are primary temperature increasing derivers (Wu et al., 2010) and lead to develop an area into a heat island. Previously, heat island effects have been reported by Wu et al. (2010) and Sajjad et al. (2009). The present findings also show a greater increase in the minimum temperature compared to the maximum temperature. Thus, indicating that nights are becoming warmer in the area. Earlier, greater increase in the minimum temperature compared to the maximum temperature has also been reported Bukhari and Bajwa (2011, 2012).

The results show significant increase of $28.88 \%$ in precipitation over MFD. These results are broadly in line with findings reported previously by Grunewald et al. (2009) and Liu et al. (2010). There was a great variability in precipitation ranging between $561.8 \mathrm{~mm} /$ annum and $1635 \mathrm{~mm} /$ annum. The results show a positive correlation between temperature and precipitation. The findings highlight the effects of increasing temperature on other climatic factors. Bukhari and Bajwa (2008) also found such relationship between temperature and precipitation. This relationship may be attributed to increased level of energy storage in atmosphere by virtue of increased temperature which influences the water cycles. Earlier, effects of temperature especially on water cycles of the earth-atmosphere system have been reported by Behbahani et al. (2009). Apart from world-wide changes in water cycles due to global warming, regional and local effects have been experienced, such as, magnitude and timing of runoff, frequency and intensity of floods and droughts, rainfall patterns etc (Jiang et al., 2008).

Tree rings can be used in various applications to reconstruct past climates, as well as, to assess the effects of recent climatic and environmental changes on tree growth (Jacoby and D'Arrigo, 1997). Several factors affect the tree ring-width and intra-ring wood characteristics. Some of these factors are unique to tree site, its age and management practices, while some are related to broader climatic factors, such as, temperature, precipitation and sunshine (Yeh and Wensel, 2000). The tree-ring contains a complete picture of climate conditions under which the tree is grown. The present results show a mean ring-width of the Blue pine of $1.05 \mathrm{~mm} / \mathrm{annum}$. The intra-ring early wood formation is $66.2 \%$, while the intra-ring late wood formation is $33.8 \%$. The ring-width and intra-ring late wood formation increases to 5.09 and $2.57 \%$ over the time period of 50 years. However, the intra-ring early wood formation decreases 1.28\%. Previously, similar effects of temperature and precipitation on ring-width and ring wood characteristics have been reported by Feliksik and Wilczynski (2009). They found that temperature and precipitation of the growing season and months preceding that season affected the annual diameter increment (increment core) of 100-year old trees of Norway spruce (Picea abies), Scots pine (Pinus sylvestris), Douglas fir (Pseudotsuga menziesii), Sitka spruce (Picea sitchensis) and Silver fir (Abies alba). Khan et al. (2013) have found temperature and precipitation function for ring-width of Cedrus deodara in Chitral-Hindukush, Pakistan.

The intra-ring wood characteristics also provide a promising indicator for assessing relationship between climate change and tree growth (Fonti et al., 2010). Among the intra-ring wood characteristics, early and late wood formation are dependent highly on climate and provide more conclusive growth-climate relationship compared to total ring-width only (Lebourgeois et al., 2010). The present results indicate positive relationship between temperature and ring-width; and between precipitation and ring-width. The intra-ring early wood formation shows a negative relationship with maximum temperature, precipitation and ring-width. The intra-ring late wood formation showed positive relationship with maximum and minimum temperature but negative relationship with mean temperature and precipitation. The intra-ring early wood formation and late wood formation are inversely related between themselves. These findings indicate improvement in wood density with changing climate in addition to enhanced growth. Thus use of ring-width combined with intra-ring wood characteristics 
gives better assessment of climate change impacts on tree growth. These findings are in conformity with Battipaglia et al. (2010) who also emphasized use of these wood characteristics for prediction of climate change impacts on tree growth.

\section{CONCLUSION}

Based on these results, it is concluded that climate over Murree Forest Division has changing significantly during time period of 1963-2012. The increase in minimum temperature $\left(1.27^{\circ} \mathrm{C}\right)$ was greater compared to maximum temperature $\left(0.60^{\circ} \mathrm{C}\right)$. Similarly, precipitation also increased over MFD. The changing climate showed significant positive impact on growth (ring-width) of $P$. wallichiana. The intra-ring late wood formation showed positive relationship with temperature (minimum and maximum) and precipitation. However, changing climate indicated adverse impacts on intra-ring early wood formation.

\section{REFERENCES}

Allen, R.G., L.S. Pereira, D. Raes and M. Smith, 1998. Crop evapotranspiration-guidelines for computing crop water requirements. FAO Irrigation and Drainage Paper No. 56, FAO, Rome, Italy. http//www.fao.org/docrep/X0490E/ x0490e00.htm.

Allen, C.D., A.K. Macalady, H. Chenchouni, D. Bachelet and N. Mcdowell et al., 2010. A global overview of drought and heat-induced tree mortality reveals emerging climate change risks for forests. For. Ecol. Manage., 259: 660-684.

Battipaglia, G., D.V. Micco, W.A. Brand, P. Linke, G. Aronne, M. Saurer and P. Cherubini, 2010. Variations of vessel diameter and $\delta 13 \mathrm{C}$ in false rings of Arbutus unedo L. Reflect different environmental conditions. New Phytol., 188: 1099-1112.

Behbahani, S.M.R., A. Rahimikhoob and M.H. Nazarifar, 2009. Comparison of some split-window algorithms to estimate land surface temperature from AVHRR data in southeastern Tehran, Iran. Desert, 14: 157-161.

Boisvenue, C. and S.W. Running, 2006. Impacts of climate change on natural forest productivityevidence since the middle of the 20th century. Global Change Biol., 12: 862-882.

Breshears, D.D., N.S. Cobb, P.M. Rich, K.P. Price and C.D. Allen et al., 2005. Regional vegetation die-off in response to global-change-type drought. Proc. Natl. Acad. Sci. USA., 102: 15144-15148.

Bukhari, S.S.B. and G.A. Bajwa, 2008. Temporal temperature rise and its effects on other climatic factors in Peshawar-Pakistan. Pak. J. For., 58: 1-18.
Bukhari, S.S.B. and G.A. Bajwa, 2011. Climate change trends over coniferous forests of Pakistan. Pak. J. For., 61: 1-14.

Bukhari, S.S.B. and G.A. Bajwa, 2012. Development of national response strategy to combat impacts of climate change on forest of Pakistan. Pakistan Forest Institute, March 2012, Peshawar, pp: 156.

Esper, J., E.R. Cook and F.H. Schweingruber, 2002. Low-frequency signals in long tree-ring chronologies for reconstructing past temperature variability. Science, 295: 2250-2253.

Falcucci, A., L. Maiorano and L. Boitani, 2007. Changes in land-use/land-cover patterns in Italy and their implications for biodiversity conservation. Landscape Ecol., 22: 617-631.

Feliksik, E. and S. Wilczynski, 2009. The effect of climate on tree-ring chronologies of native and nonnative tree species growing under homogenous site conditions. Geochronometria, 33: 49-57.

Foley, J.A., R. DeFries, G.P. Asner, C. Barford and G. Bonan et al., 2005. Global consequences of land use. Science, 309: 570-574.

Fonti, P., G. von Arx, I. Garcia-Gonzalez, B. Eilmann, U. Sass-Klaassen, H. Gartner and D. Eckstein, 2010. Studying global change through investigation of the plastic responses of xylem anatomy in tree rings. New Phytol., 185: 42-53.

Grunewald, K., J. Scheithauer, J.M. Monget and D. Brown, 2009. Characterisation of contemporary local climate change in the mountains of southwest Bulgaria. Clim. Change, 95: 535-549.

IPCC., 2007. Climate change 2007: Synthesis report: Contribution of working groups I, II and III to the fourth assessment report of the intergovernmental panel on climate change. IPCC, Geneva, Switzerland, pp: 1-104.

Jacoby, G.C. and R.D. D'Arrigo, 1997. Tree rings, carbon dioxide and climatic change. Proc. Natl. Acad. Sci. USA., 94: 8350-8353.

Jiang, T., Z.W. Kundzewicz and B. Su, 2008. Changes in monthly precipitation and flood hazard in the Yangtze River Basin, China. Int. J. Climatol., 28: 1471-1481.

Khan, N., M. Ahmed and S.S. Shaukat, 2013. Climatic signal in tree-ring chronologies of Cedrus deodara from Chitral Hindukush range of Pakistan. Pak. J. Bot., 40: 195-207.

Kirschbaum, M.U.F., 2000. Forest growth and species distribution in a changing climate. Tree Physiol., 20: 309-322.

Knutson, T.R., T.L. Delworth, K.W. Dixon, I.M. Held, J. Lu, V. Ramaswamy and M.D. Schwarzkopf, 2006. Assessment of twentieth-century regional surface temperature trends using the GFDL $\mathrm{CM}_{2}$ coupled models. J. Clim., 19: 1624-1651. 
Lebourgeois, F., C.B.K. Rathgeber and E. Ulrich, 2010. Sensitivity of French temperate coniferous forests to climate variability and extreme events (Abies alba, Picea abies and Pinus sylvestris). J. Veg Sci., 21: 364-376.

Liu, B., H. Henderson, Y. Zhang and M. Xu, 2010. Spatiotemporal change in China's climatic growing season: 1955-2000. Clim. Change, 99: 93-118.

Roberts, T.J., 1992. The Birds of Pakistan. Vol. 2, Oxford University Press, Karachi, Pages: 541.

Sajjad, S.H., B. Hussain, M.A. Khan, A. Raza, B. Zaman and I. Ahmed, 2009. On rising temperature trends of Karachi in Pakistan. Clim. Change, 96: 539-547.

Sala, O.E., F.S. Chapin, J.J. Armesto, E. Berlow and J. Bloomfield et al., 2000. Global biodiversity scenarios for the year 2100. Science, 287: 1770-1774.

Siddiqui, K.M., I. Mohammad and M. Ayaz, 1999. Forest ecosystem climate change impact assessment and adaptation strategies for Pakistan. Clim. Res., 12: 195-203.
Urban, D.L. and H.H. Shugart, 1989. Forest Response to Climate Change: A Simulation Study for Southeastern Forests. In: The Potential Effects of Global Climate Change on the United States, Smith, J.B. and D.A. Tirpak (Eds.). U.S. Environmental Protection Agency, Washington, DC.

Vorholz, F., 2009. Global climate protection. Deutschland, 5: 8-13.

Wu, Z., H. Zhang, C.M. Krause and N.S. Cobb, 2010. Climate change and human activities: A case study in Xinjiang, China. Clim. Change, 99: 457-472.

Yeh, H.Y. and L.C. Wensel, 2000. The relationship between tree diameter growth and climate for coniferous species in northern California. Can. J. For. Res., 30: 1463-1471. 